\title{
TALKEY SHOWS E IMPRENSA: UMA LEITURA BASEADA NA ANÁLISE CRÍTICA DO DISCURSO
}

\author{
Maria Stella Galvão Santos ${ }^{1}$
}

Resumo: O objeto desta comunicação é analisar os pronunciamentos do presidente Jair Bolsonaro no contato diário mantido com repórteres, na saída do Palácio da Alvorada, em Brasília, batizados por seus assessores de "Talkey shows". Destacaremos dois episódios que explicitam o grau de esgarçamento da relação entre jornalistas e o chefe do Executivo nacional. O do "furo" dirigido à jornalista Patrícia Campos Mello, da Folha de S. Paulo, e o das bananas oferecidas aos repórteres por um humorista durante um "talkey show", respectivamente nos meses de fevereiro e março deste ano. Utilizaremos as ferramentas teóricas da Análise Crítica do Discurso, vertente teórica que postula o uso social da linguagem em interações nas quais se estabelecem relações de poder e dominação por grupos econômicos e políticos que utilizam a linguagem como forma de controle social, por meio de várias formas de práticas discursivas. Inclusive a chacota e a demonização da imprensa, no caso em exame. Utilizamos como referencial teórico Van Dijk (1990, 2009, 2011, 2017), Fairclough (2003), Charaudeau (2003, 2015) e Sodré (2017), entre outros, recorrendo às ferramentas de viés linguístico para analisar as relações entre linguagem, poder e controle social.

Palavras-chave: Imprensa. Análise Crítica do Discurso. Talkey shows.

\begin{abstract}
The purpose of this communication is to analyze President Jair Bolsonaro's pronouncements in his daily contact with reporters outside the Palacio da Alvorada in Brasilia, baptized by his advisors of "Talkey shows". We will focus on two episodes that explain the degree of breakdown in the relationship between journalists and the head of the national executive. The "scoop" episode, aimed at journalist Patrícia Campos Mello, from Folha de S. Paulo, and the bananas offered to reporters by a comedian during a "talkey show", in February and March of this year, respectively. We will use the theoretical tools of Critical Discourse Analysis, a theoretical aspect that postulates the social use of language in interactions in which power relations and domination are established by economic and political groups that use language as a form of social control, through various forms of discursive practices, such as mockery and demonization of the press. We use as theoretical references Van Dijk (1990, 2009, 2011, 2017), Fairclough (2003), Charaudeau (2003, 2015) and Sodré (2017), among others, using linguistic tools to analyze the relationships between language, power and social control.
\end{abstract}

Keywords: Press. Critical Discourse Analysis. Talkey shows.

\footnotetext{
${ }^{1}$ Jornalista, doutora em Educação pela Universidade Federal do Rio Grande do Norte, aluna de Letras Língua Espanhola (UFRN), Natal-RN, Brasil. E-mail: stellag@uol.com.br.
} 
Resumen: El propósito de esta comunicación es analizar los pronunciamientos del presidente Jair Bolsonaro en el contacto diario con los reporteros en las cercanías del Palacio de la Alvorada, en Brasilia, bautizados por sus asesores de "Talkey Shows". Destacaremos dos episodios que explican el grado de fricción en la relación entre periodistas y el jefe del ejecutivo nacional. El del "furo" dirigida a la periodista Patrícia Campos Mello, de Folha de S. Paulo, y los plátanos ofrecidos a los periodistas por un comediante durante un "show de charla", respectivamente, en febrero y marzo de este año. Utilizaremos las herramientas teóricas del Análisis Crítico del Discurso, un aspecto teórico que postula el uso social del lenguaje en las interacciones en las que las relaciones de poder y dominación son establecidas por grupos económicos y políticos que usan el lenguaje como una forma de control social, a través de diversas formas prácticas discursivas incluyendo la burla y la demonización de la prensa. Utilizamos Van Dijk (1990, 2009, 2011, 2017), Fairclough (2003), Charaudeau (2003, 2015) y Sodré (2017), entre otros, utilizando herramientas de sesgo lingüístico para analizar las relaciones entre lenguaje, poder y control social.

Palabras-clave: Prensa. Análisis crítico del discurso. Talkey shows.

\section{Introdução}

Este artigo se propõe a analisar a prática discursiva do presidente Jair Bolsonaro em duas circunstâncias nas quais a relação conflituosa do chefe do Estado brasileiro com jornalistas chegou às raias do paroxismo, produzindo uma reação em cadeia dos meios de comunicação, das entidades representativas do setor, além de políticos de diferentes legendas. A nosso ver, os dois episódios explicitam a tática bolsonarista de demonizar os repórteres e os veículos que representam, apontando para uma intrincada relação entre a fala e as iniciativas concretas do governo. Líder de um governo marcado por enfrentamentos praticamente diários com jornalistas, Bolsonaro elevou a tensão no embate com o campo jornalístico em diversas oportunidades ao longo de 17 meses iniciais do mandado de quatro anos.

Esta análise se propõe, ainda, a desvelar os mecanismos pelos quais o atual mandatário do país transformou entrevistas coletivas diárias em um misto de espetáculo pessoal em tons histriônicos e em festival de desaforos vociferados para os profissionais de diversos veículos de comunicação, entre impressos, meios digitais, rádios e TV's. Busca, ainda, expor os artifícios utilizados por aqueles que controlam o discurso público e engendram estratégias que determinarão o teor das informações disseminadas. Ainda que desarticuladas e não raro burlescas, são elas que circularão no espaço público.

Uma das particularidades de tais "shows" é seu protagonista não admitir que jornalistas no exercício das atividades profissionais questionem declarações e ações do 
PERcursos Linguísticos • Vitória (ES) •v. 10 •n. 25 • 2020 • ISSN: 2236-2592 • Dossiê:

\section{Discursos de resistência e corpos (re)existentes •}

governo. Quando isso ocorre, ele sobe o tom agressivo e encerra abruptamente a entrevista. O discurso diário de Bolsonaro nos arredores do Palácio da Alvorada, invariavelmente aplaudido pelos simpatizantes presentes, foi apelidado por assessores palacianos de talk show e adaptado para "talkey show", devido ao vício de linguagem dele, de terminar frases com a pergunta "tá ok?". Esta análise está baseada em dois episódios paradigmáticos do enfrentamento a que nos referimos acima, ocorridos em fevereiro e março/2020, selecionados em função de representarem um ataque frontal aos profissionais de imprensa e que geraram ampla repercussão junto à opinião pública e aos meios de comunicação.

Inicialmente, abordaremos os pressupostos conceitos da metodologia empregada, Análise Crítica do Discurso (ACD), seguindo-se os relatos episódicos dos textos (ou discursos, melhor compreendido), seu contexto e repercussão. Trata-se de um recorte metodológico que se propõe a destacar eventos episódicos como exemplos de uma prática corrente em dado contexto, no caso, o atual cenário político brasileiro. Contemplado desde meados dos anos 1960, este campo de estudos se institucionalizou de forma mais explícita a partir da década de 1980. Este tipo de análise bebe, entre outras fontes, na Linguística Crítica, conduzida no final da década de 1970 na Inglaterra por Roger Fowler, que propôs ferramentas de viés linguístico para analisar as relações entre linguagem, poder e controle social. Nesta direção convergem as ideias do também britânico Norman Fairclough, para quem a prática discursiva é indissociável da prática social.

Diferentes discursos são diferentes perspectivas sobre o mundo, e eles estão associados com as distintas relações que as pessoas assumem com o mundo, o que, por sua vez, depende de suas posições no mundo, suas identidades sociais e pessoais, e as relações sociais que elas instauram com os outros. Discursos não só representam o mundo como ele é (ou melhor, como ele é visto que é); eles são também projetivos, imaginários, representando mundos possíveis que são diferentes do mundo real, e ligados a projetos para mudar o mundo em determinadas direções. (FAIRCLOUGH, 2003, p. 124)

\section{Diferentes âmbitos da análise do discurso}

De fato, como abordagem metodológica para análise de manifestações pessoais ou institucionais (discursivas, portanto), a análise do discurso se constituiu em um campo de pesquisa cujo objetivo é compreender a produção social de sentidos realizada por sujeitos históricos, utilizando-se de linguagens de uso corrente para disseminar informações e pontos de vista. Segundo van Dijk (2011), em Ideología y Discurso, os mais variados recursos, como as 
PERcursos Linguísticos • Vitória (ES) •v. 10 •n. 25 • 2020 • ISSN: 2236-2592 • Dossiê:

\section{Discursos de resistência e corpos (re)existentes •}

figuras de linguagem ou a estrutura textual utilizada por um grupo de agentes sociais acerca de outro, desempenham funções ideológicas dentro do discurso. Como afirma o autor, o significado do discurso não se limita ao significado das palavras e frases. "O discurso também conta com significados mais globais, como os "temas", que representam a informação mais importante do discurso e explicam do que este trata em geral." (van Dijk, 2011, p. 59). Especialmente na medida da sua redundância, como na ênfase do presidente ao dirigir-se em tom ofensivo à imprensa. E, de acordo com Fairclough (2003, p. 22), "qualquer evento discursivo (isto é, qualquer exemplo de discurso) é considerado simultaneamente um texto, um exemplo de prática discursiva e um exemplo de prática social”.

Por outro lado, ainda que as agressões sistemáticas aos profissionais de imprensa por parte do chefe do Executivo apareçam com frequência no noticiário, elas podem ser inferidas a partir da análise do conjunto textual do fato reportado. "Na condição de analistas críticos, podemos mostrar como determinados elementos léxicos ou metáforas são utilizados com o propósito de construir os detalhes dos acontecimentos ou as características de algumas pessoas nesses modelos mentais.” (Van Dijk, 2009, p. 48). Utilizaremos alguns níveis de análise propostos por este autor, seja por sua aplicabilidade a diversos âmbitos discursivos ou porque o modelo defendido por este autor reporta-se, de modo geral, a texto (discurso) e contexto (social e cognitivo). A análise do teor discursivo das falas presidenciais será feita em três tópicos relacionados ao significado daquilo que é proferido, a saber:

a) Temas: Representam a informação mais importante e explicam a abordagem do discurso.

b) Nível de descrição: Fornece muitos ou poucos detalhes sobre um fato, ou descreve-o de maneira específica ou abstrata e geral.

c) Exemplos e ilustrações: Uso de narrativas e ilustrações que servem de apoio às proposições e argumentos. Neste tópico inscrevemos duas imagens obtidas por fotojornalistas durante os episódios analisados, de maneira a destacar os aspectos da representação e processamento visual do contexto, como pontuado por van Dijk. (2017, p. 123)

Há, ainda, a categoria das estruturas proposicionais também elencadas por Van Dijk para análise de como o significado do discurso se organiza e pode ser decomposto em assertivas ou proposições. Uma frase expressa uma ou mais ideias que podem ser verdadeiras ou falsas ou expressam um "pensamento completo" (van Djik, 2011, p. 25) Esta modalidade se adequa ao emissor presidencial, cujas expressões preferenciais, no calor do embate com os jornalistas, são sentenças soltas e pontuadas por interrogações ou impropérios. As estruturas 
PERcursos Linguísticos • Vitória (ES) •v. 10 •n. 25 • 2020 • ISSN: 2236-2592 • Dossiê:

Discursos de resistência e corpos (re)existentes •

proposicionais que compõem um discurso podem lançar mão de pressuposições e generalizações, buscando efeitos de verdade a partir de ocorrências e/ou declarações pontuais.

\section{Dois discursos paradigmáticos do conflito}

No histórico dos embates de Bolsonaro com profissionais da apuração jornalística, destacamos dois eventos marcantes, ambos ocorridos no primeiro trimestre de 2020. Preliminarmente, é importante citar que tais eventos se inscrevem nos chamados Talkeys Shows ${ }^{2}$, encontros diários do presidente com jornalistas e apoiadores na saída da residência oficial, em Brasília. Nesses encontros diários, o roteiro do mandatário que atua como portavoz do próprio governo inclui dar recados a aliados e adversários, comentar acontecimentos e hostilizar, com agressões verbais e eventualmente gestuais, a repórteres, fotógrafos e cinegrafistas. Na segunda semana de fevereiro/2020, Bolsonaro mandou uma repórter da Folha "calar a boca", ao ser questionado sobre o conflito de interesses envolvendo o chefe da Secretaria de Comunicação, Fabio Wajngarten, sócio de uma empresa que tem clientes contratados pelo governo.

O primeiro entrevero grave que é objeto desta análise envolveu uma jornalista da Folha de S.Paulo, Patrícia Campos Mello, que se notabilizou especialmente por reportagens sobre a compra de mensagens ilegais por apoiadores do então candidato à presidência pelo PSL. Em 18 de outubro de 2018, o escândalo veio à tona sob o título "Empresários bancam campanha contra o PT pelo WhatsApp". A investigação, tema de várias reportagens de Mello, tornou-a alvo de mensagens de ódio e notícias falsas na Internet, e foi um dos fatores geradores da CPMI (Comissão Parlamentar Mista de Inquérito) das Fake News ${ }^{3}$, criada em setembro/2019 no Congresso Nacional.

Ao contrário do que preconiza Charaudeau (2003), ao afirmar que a linguagem não é transparente e apresenta sua própria opacidade mediante a qual se constrói uma visão e sentido particular de mundo, a verborragia do atual ocupante do Palácio do Planalto produz um sentido explicitamente insultuoso em todas as ocasiões nas quais ele ou seu governo foram confrontados com perguntas incômodas por parte dos profissionais de imprensa. A

\footnotetext{
${ }^{2}$ Disponível em <https://www1.folha.uol.com.br/poder/2020/01/talkey-show-de-bolsonaro-reune-ex-petistaspadres-e-youtubers-no-alvorada.shtml >. Último acesso em 15/4/20.

${ }^{3}$ A CPMI foi instalada em setembro de 2019 para investigar, no prazo de 180 dias, "os ataques cibernéticos que atentam contra a democracia e o debate público; a utilização de perfis falsos para influenciar os resultados das eleições 2018; a prática de cyberbullying sobre os usuários mais vulneráveis da rede de computadores, bem como sobre agentes públicos; e o aliciamento e orientação de crianças para o cometimento de crimes de ódio e suicídio". Fonte: <https://www.bbc.com/portuguese/brasil-51745900>. Último acesso em 10/4/20.
} 
mecânica de construção do sentido produzida pelos meios de comunicação, como afirma Charaudeau, resulta "da imbricação das condições extradiscursivas e das realizações intradiscursivas" (2015, p. 40). Ou seja, as ideias que habitam os discursos nascem de uma lógica discursiva interiorizada e, simultaneamente, reagem ao peso das circunstâncias e dos interesses nos e pelos quais são produzidas. No caso de Bolsonaro, esta lógica está centrada em uma tática de confrontação simbolicamente belicista e não raro baseada em inverdades. Buscamos, assim, examinar o impacto do discurso presidencial em seu intento de desqualificar o trabalho da imprensa e relativizar seu papel no Brasil atual.

Em 18 de fevereiro/2020, sob o título "Bolsonaro insulta repórter da Folha com

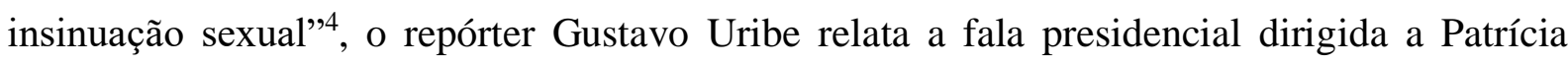
Mello no encontro com jornalistas no chamado "cercadinho" do Palácio da Alvorada, em Brasília" "Ela queria um furo. Ela queria dar o furo $^{6}$ [risos dele e dos demais] a qualquer preço contra mim.” A declaração referia-se ao depoimento de um ex-funcionário de uma agência de disparos de mensagens em massa por WhatsApp que havia sido dado na semana anterior à CPMI das Fake News. No mesmo dia do insulto público dirigido à repórter, a Folha de S.Paulo emitiu nota de repúdio: “O presidente da República agride a repórter Patrícia Campos Mello e todo o jornalismo profissional com a sua atitude. Vilipendia também a dignidade, a honra e o decoro que a lei exige do exercício da Presidência”.

Ainda no dia 18, à tarde, ao deixar o Palácio da Alvorada após reunião com ministros, como relata reportagem do portal $\mathrm{G}^{7}$, do grupo Globo de Comunicação, Bolsonaro voltou ao tema, conhecedor da repercussão e dos ruídos produzidos pela grosseria destilada na manhã daquele dia. "Alguém da Folha de S.Paulo aí? Eu agredi sexualmente uma repórter hoje? Parabéns à mídia aí. Não quero conversa.”

Esta construção discursiva se insere na ideia de que modelos mentais precedem um acontecimento ou manifestação. "Na análise ideológica do discurso, é muito importante estudar porque estão explícitos alguns significados inferidos de uma frase ou um texto. A

\footnotetext{
${ }^{4}$ Disponível no link <https://www1.folha.uol.com.br/poder/2020/02/bolsonaro-insulta-reporter-da-folha-cominsinuacao-sexual.shtml $>$. Último acesso em 10/4/20.

5 O "cercadinho" do Palácio da Alvorada ganhou notoriedade ao longo do primeiro 1,5 ano de mandado de Jair Bolsonaro. É ali que ele fala ou esbraveja com os jornalistas, após deixar o local, no início das manhãs, e onde se dirige aos apoiadores que formam uma claque ruidosa a cada xingamento ou vitupério em tom jocoso dirigido aos profissionais de imprensa. Estes estão separadas dos apoiadores por uma grade.

${ }^{6}$ Furo, no jargão da imprensa, refere-se à informação exclusiva obtida por jornalistas. Assim, um veículo "fura" os demais ao publicar essa informação que só ele dispõe, por mérito dos seus profissionais.

${ }^{7}$ Disponível no link <https://g1.globo.com/politica/noticia/2020/02/18/bolsoro-repete-declaracao-de-empresariode-que-jornalista-ofereceu-sexo-por-informacao.ghtml>. Último acesso em 10/04/20.
} 
opção de expressar uma informação ou deixá-la implícita não é neutra.” (van Dijk, 2011, p. 60). É possível referir-se aos jornalistas utilizando muitas expressões e descrições mais ou menos sinônimas, mas os significados nos usos e nas implicações ideológicas serão diferentes. Outras propriedades semânticas do discurso se definem na relação entre proposições como as paráfrases, expressões cujo significado é aproximado mas não configuram sinônimos. O trecho "parabéns à mídia aî” unifica no termo mídia ${ }^{8}$ uma referência que se tornou recorrente no imaginário popular aos meios de comunicação, incluídos os produtos de entretenimento, em frases como "a culpa da mídia" ou "a mídia impõe padrões". No caso da fala de Bolsonaro, o advérbio "aí" transforma-se em interjeição e agrega uma condição intrinsecamente reducionista da chamada "mídia". Como pontua Charaudeau (2003), cada discurso modula seus efeitos de verdade de uma maneira particular.

No caso do discurso da informação, este modula esses efeitos de acordo com o que se poderia considerar razões pelas quais se transmite uma informação, segundo as características particulares e sociais de quem fornece a informação (identidade e segundo os meios que utiliza para provar sua veracidade. (CHARAUDEAU, 2003:60)

Um aspecto estratégico a ser analisado nos estudos de comunicação [nos referimos, aqui, à comunicação institucional promovida por detentor de cargo público] é, conforme Bourdieu (1989), a maneira pela qual o campo político e o campo midiático transformam-se em um complexo espaço de lutas simbólicas que são atravessadas pela figura fundamental da palavra do porta-voz (o político, o líder comunitário, a fonte, o âncora, o repórter etc.): “O porta-voz é aquele que, ao falar de um grupo, ao falar em lugar de um grupo, põe subrepticiamente a existência do grupo em questão, institui este grupo, pela operação de magia que é inerente a todo o ato de nomeação.” (BOURDIEU, 1989, p. 159). O que faz o poder das palavras e das palavras de ordem - como diagnostica o sociólogo que se debruçou sobre a seara dos discursos informativos - ou, melhor dizendo, "o poder de manter a ordem ou de a subverter é a crença na legitimidade das palavras e daquele que as pronuncia, crença cuja produção não é da competência das palavras”. (idem, pp. 14-15).

\footnotetext{
${ }^{8}$ Os primeiros teóricos dos meios de comunicação empregaram a palavra latina media. Como eram teóricos de língua inglesa, diziam: mass media, isto é, os meios de massa. A pronúncia, em inglês, do latim media é "mídia". Quando os teóricos de língua inglesa dizem "the media", estão dizendo: "os meios". Por apropriação da terminologia desses teóricos no Brasil, a palavra "mídia" passou a ser empregada como se fosse uma palavra feminina no singular - "a mídia”. (CHAUÍ, 2006, p. 35).
} 
Em artigo publicado na Folha em 8 de março, intitulado "No Brasil, ser mulher nos transforma em alvo de ataques"," Patrícia Mello detalhou as razões da fala misógina e grosseira a ela dirigidas pelo titular do executivo federal. O linchamento virtual, como qualifica Mello, começou depois que Hans River do Rio Nascimento, ex-funcionário da agência de marketing Yacows, fez um depoimento à CPMI das Fake News. Hans foi entrevistado para a reportagem "Fraude com CPF viabilizou disparo de mensagens de WhatsApp na eleição", publicada pela Folha em 2 de dezembro de 2018 e escrita pelos repórteres Artur Rodrigues e Patrícia Campos Mello. Ela esclareceu que a reportagem, baseada em documentos públicos da Justiça do Trabalho, fotos, planilha e em relatos de Hans, mostrou que uma rede de empresas, entre elas a Yacows, recorreu ao uso fraudulento de nome e CPFs de idosos para registrar chips de celular e garantir o disparo de lotes de mensagens em benefício de políticos. "Em seu depoimento à CPMI, Hans contou diversas mentiras, entre elas a de que eu teria tentado obter informação 'a troco de sexo'."

\section{Bananas simbólicas e reais}

O acirramento das reações raivosas do presidente da República aos questionamentos dos jornalistas no "cercadinho" da Alvorada teve no gesto de "dar uma banana" à imprensa uma representação paradigmática do desprezo do nosso personagem pelos profissionais que cumprem a pauta diária e obrigatória de acompanhar a movimentação pública da autoridade máxima do Executivo. No início, o gesto foi usado em pelo menos duas vezes antes daquela que se converteria em um case da comédia de stand up imiscuída na política brasileira. Em 8/fevereiro, de forma inédita, a reação envolveu a conhecida maneira de demonstrar desdém, sujeitar o antebraço direito com a mão esquerda e levantar o braço direito com o punho cerrado em direção ao próprio rosto. A "banana" (Foto 1) direcionada ao grupo de profissionais que portavam microfones, gravadores e câmeras foi a resposta do presidente às perguntas dos repórteres relacionadas à repercussão negativa a uma declaração sua, três dias antes, sobre pessoas com HIV representarem uma despesa para o país. Portadores de HIV, conforme registro da BBC Brasil de 6/fevereiro ${ }^{10}$ utilizaram a hashtag \#EuNaoSouDespesa para criticar declaração de Bolsonaro sobre o tema.

\footnotetext{
${ }^{9}$ Disponível no link <https://www1.folha.uol.com.br/poder/2020/03/depoimento-no-brasil-ser-mulher-nostransforma-em-alvo-de-ataques.shtml>. Último acesso em 10/04/20.

${ }^{10}$ Disponível no link <https://www.bbc.com/portuguese/brasil-51409101>. Último acesso em 10/04/20.
} 


\section{Foto 1}

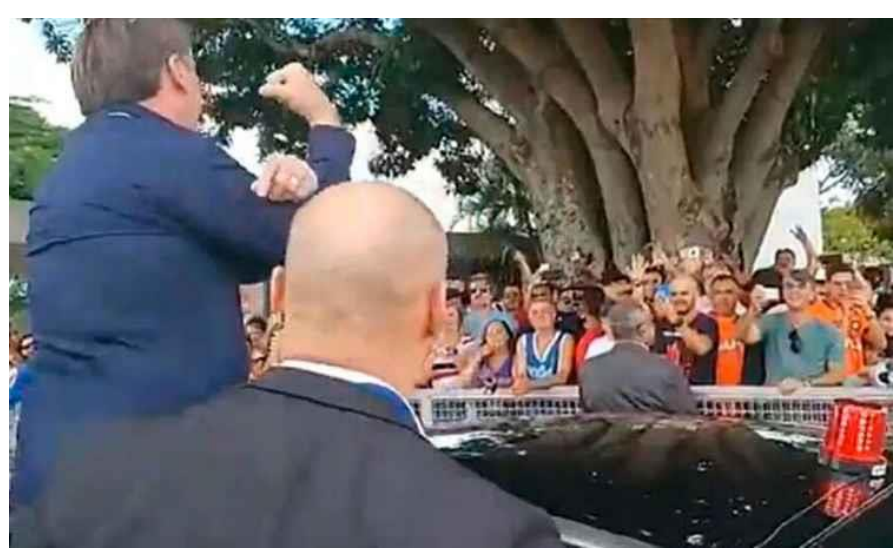

Fonte: Último Segundo (15/02/2020). Crédito: Reprodução

A segunda "banana" foi motivada por perguntas sobre o desmonte da tradicional Biblioteca da Presidência da República, no Anexo I do Palácio do Planalto, para abrigar a equipe do programa Pátria Voluntária, coordenado pela primeira-dama, Michelle Bolsonaro. Em registro de O Correio Braziliense ${ }^{11}$ de 15/fevereiro/2020, disse o marido de Michelle: "Vocês só se preocupam com besteira. Nenhum livro vai embora, vai ficar tudo lá. [...] Em vez de vocês elogiarem, vocês criticam. Tenha paciência. Quem age assim merece uma banana".

O melhor, em termos de metáfora abusiva no trato com os jornalistas, estava por vir. Nenhum gesto foi tão depreciativo das atitudes do governante frente à imprensa quanto o aval dado à performance do comediante Márvio Lúcio, o Carioca. Na manhã de 4 de março, ele chegou à área externa do Palácio da Alvorada pouco antes do presidente, em um carro oficial, fantasiado de Jair Bolsonaro e com faixa presidencial, oferecendo bananas reais e simultaneamente simulacros, aos jornalistas (Foto 2).

Na Folha de S. Paulo ${ }^{12}$, a notícia sobre a insólita apresentação foi veiculada na editoria de Economia, que atribuiu o cenário e seu teor a uma estratégia diversionista montada pelo governo, como explicita o título da reportagem: “Após PIB desacelerar, Bolsonaro usa humorista para evitar assunto". O tema do dia era o de que a economia brasileira, mensurada

\footnotetext{
${ }^{11}$ Disponível no seguinte endereço, acessado em 15/03/20: <https://www.correiobraziliense.com.br/app/noticia/politica/2020/02/15/interna_politica,828365/bolsonarovolta-a-dar-banana-a-jornalistas-so-se-preocupam-com-beste.shtml>

12 Disponível no link <https://economia.uol.com.br/noticias/redacao/2020/03/04/apos-pib-desacelerar-bolsonarousa-humorista-para-evitar-assunto.htm>. Último acesso em 10/04/20.
} 
PERcursos Linguísticos • Vitória (ES) •v. 10 •n. 25 • 2020 • ISSN: 2236-2592 • Dossiê:

Discursos de resistência e corpos (re)existentes •

pelos números atrelados ao Produto Interno Bruto (PIB), havia crescido apenas 1,1\% em 2019, primeiro ano do novo governo, pior desempenho dos últimos três anos, segundo a reportagem da Folha de S. Paulo. Quando o presidente chegou à cena montado com o ator e as bananas [fartamente distribuídas entre os ruidosos apoiadores do governo], os repórteres prontamente quiserem ouvi-lo sobre a pífia atividade econômica do ano anterior. "PIB? O que é PIB? Pergunta para eles [jornalistas] o que é PIB", disse Bolsonaro ao humorista, ambos às gargalhadas.

Foto 2

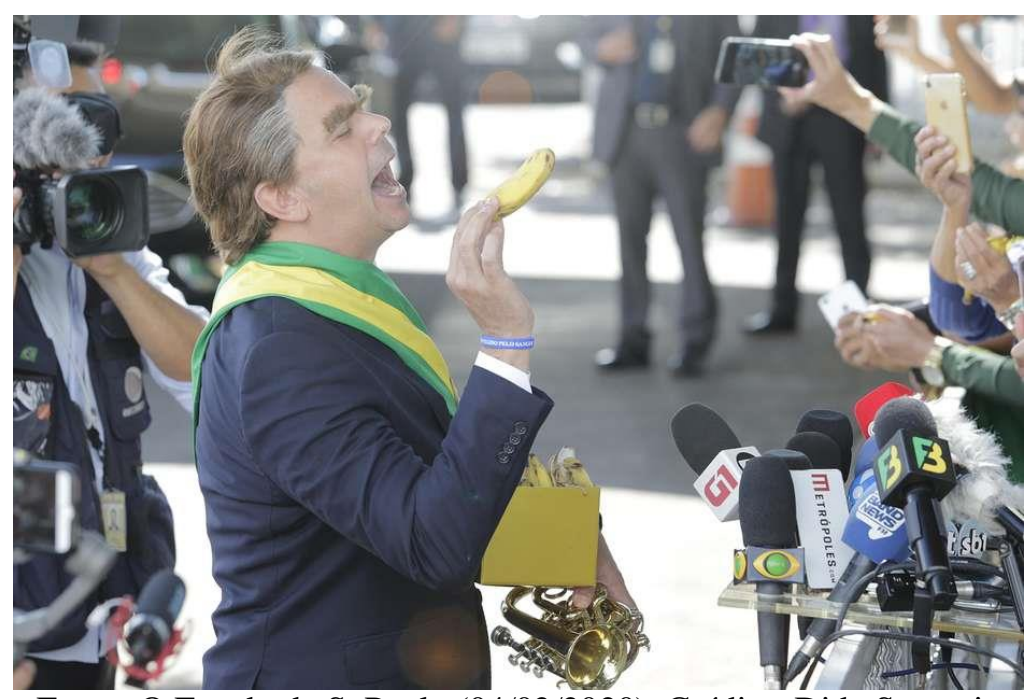

Fonte: O Estado de S. Paulo (04/02/2020). Crédito: Dida Sampaio

\section{Os discursos sob análise}

No primeiro episódio objeto desta análise, em 18 de fevereiro, pela primeira vez a fala do presidente é dirigida a um profissional de imprensa em particular, a jornalista Patrícia Campos Mello, cujas reportagens estavam no centro das audiências e depoimentos colhidos pela CPMI das Fake News [instalada na Câmara dos Deputados em setembro/2019]. A íntegra 
PERcursos Linguísticos • Vitória (ES) •v. 10 •n. 25 • 2020 • ISSN: 2236-2592 • Dossiê:

Discursos de resistência e corpos (re)existentes •

da passagem discursiva feita na manhã daquele dia no "cercadinho da Alvorada" foi extraída da edição online do jornal Correio Braziliense. ${ }^{13}$ Segue o teor integral:

“Olha a jornalista da Folha de S.Paulo. Tem mais um vídeo dela aí. Não vou falar aqui porque tem senhoras aqui do lado. Ela falando: 'Eu sou 'tá, tá, tá' do PT', tá certo? No depoimento do Hans River, no final de 2018, para o Ministério Público, ele diz do assédio da jornalista em cima dele. Ela [repórter] queria um furo. Ela queria dar um furo a qualquer preço contra mim. Lá em 2018, ele [Hans] já dizia que ela chegava e ia perguntando: 'O Bolsonaro pagou para você divulgar pelo Whatsapp informações?' E outra: se você fez fake news contra o PT, menos com menos dá mais na matemática. Se eu for mentir contra o PT, eu estou falando bem porque o PT só fez besteira."

O tema abordado pelo presidente foi extraído, em verdade, de uma ocorrência factual, o depoimento de Hans River à CPMI em 11/fevereiro/2020, quando este repetiu o mesmo argumento já utilizado junto ao Ministério Público Eleitoral, em dezembro/2018, alegando um hipotético assédio, prontamente rechaçado pela jornalista. Bolsonaro voltou ao tema usando a palavra "furo" em duplo sentido, somando ao jargão jornalístico a clara associação com a disponibilidade sexual de uma mulher ou ainda mais expressamente, à sua genitália. "Ela queria um furo. Ela queria dar um furo a qualquer preço contra mim", disse aos risos, entre gargalhadas da plateia.

O nível de descrição é sofrível, limitando-se a frases soltas com interjeições que se tornaram a marca registrada do político: isso aí, tá certo, tá ok, invariavelmente em tom interrogativo, buscando a complacência e identificação dos interlocutores. Inexiste qualquer preocupação de contextualizar o comentário, que principia de maneira aleatória. "Olha a jornalista da Folha de S. Paulo, mais um vídeo dela aí." Na sequência, aparece de maneira confusa uma onomatopeia, "tá tá tá do PT" para sugerir que a repórter disse ter votado no Partido dos Trabalhadores. A legenda partidária é usada no curso da frase com exemplo, de maneira repetida, configurando, à maneira obsessiva, um pleonasmo. No período de oito linhas que compõem a fala atabalhoada do titular do Executivo, o partido adversário é citado quatro vezes.

No segundo episódio marcante do embate do presidente frente aos repórteres, o tema é, na realidade, uma metáfora despida de qualquer indício de sutileza. A banana brandida pelo

\footnotetext{
${ }^{13}$ Disponível no seguinte endereço, acessado em 15/03/20: <https://www.correiobraziliense.com.br/app/noticia/politica/2020/02/18/interna_politica,828834/bolsonarosobre-reporter-da-folha-ela-queria-dar-um-furo-jornal-reage.shtml $>$.
} 
PERcursos Linguísticos • Vitória (ES) •v. 10 •n. 25 • 2020 • ISSN: 2236-2592 • Dossiê:

Discursos de resistência e corpos (re)existentes •

comediante Carioca é uma metáfora ilustrativa e significa, na prática, um escarnecimento frente ao trabalho desenvolvido pelos profissionais de imprensa, um gesto de desprezo poucas vezes ousado por um político em atividade. Vejamos o diálogo travado entre repórteres e os dois "presidentes":

Repórter: Presidente Bolsonaro, o senhor falará sobre o PIB?

Bolsonaro: PIB? O que é PIB?

Carioca: O que é PIB? Paulo Guedes, Paulo Guedes...

Repórter: A pergunta é para o presidente, não pro senhor. Bolsonaro: Posto Ipiranga.

Carioca: Posto Ipiranga.

Bolsonaro: Outra pergunta.

Carioca: Outra pergunta, outra pergunta.

Repórter: Presidente, comenta o PIB conosco.

Carioca: Mas é o Paulo Guedes, é o Paulo Guedes.

A cena, batizada em coluna da Folha de S. Paulo como "Circo Bolsonaro"14, representa "o contorcionismo que Jair Bolsonaro faz para não responder perguntas indesejadas”, escreveu a colunista Mariliz Pereira Jorge em 5/março. A intervenção também configura a chamada entrevista anedótica, caracterizada por "conversações frívolas, ineptas, complacentes". (MEDINA, 1986, p. 14). A autora agrupa as entrevistas em duas tendências: a de espetacularização e a de compreensão [aprofundamento]. $\mathrm{Na}$ primeira, sobressai o grotesco, o picante, os traços sensacionalistas (idem, p. 16).

Inexiste qualquer descrição acerca da cena montada além de atuar, como já relatado, como cortina de fumaça para encobrir o mau desempenho do PIB brasileiro em 2019. O comediante reforça o caráter histriônico da cena repetindo, qual ventríloquo, o que é perguntado ao presidente. Este tipo de caso é apenas um dos efeitos da relação invertida entre acontecimento e informação, como pondera Sodré ao citar uma máxima de Baudrillard segundo a qual "a informação do acontecimento é substituída pelo acontecimento da informação" (BAUDRILLARD apud SODRÉ, 2012, p. 134). Ou seja,

\footnotetext{
${ }^{14}$ Disponível em <https://www1.folha.uol.com.br/colunas/marilizpereirajorge/2020/03/circo-bolsonaro.shtml>. Último acesso em 10/05/20.
} 
Quando a informação é parte ativa no acontecimento, o sujeito da recepção (o público leitor ou espectador) é lançado na incerteza quanto a qualquer verdade da ocorrência, o que concorre para neutralizar a ideologia "realista" do discurso informativo (logo a objetividade da notícia) e aproximá-lo dos discursos em que reinam os efeitos mitológicos, como os da publicidade e os da performance espetacular, em que se tornam irrelevantes as distinções entre o verdadeiro e o falso. (idem)

Em “A narração do fato, notas para uma teoria do acontecimento", Sodré sustenta que há certas características, nas narrativas jornalísticas, que podem provocar uma sensação de ordenamento e segurança na experiência do cotidiano de leitores habituais. "O acontecimento jornalístico reaviva em cada indivíduo o sentimento de mundo, quando não uma reacomodação sensível do cotidiano, amenizando, senão neutralizando, a impotência terapêutica coletiva." (SODRÉ, 2012, p. 97).

A contribuição de Bourdieu neste campo é decisiva para explicitar os mecanismos simbólicos entranhados nas mensagens que circulam no meio social, incluídas as de mídias massivas. $\mathrm{O}$ autor propõe que o que circula no mercado linguístico não é exatamente a língua corrente, "mas discursos estilisticamente caracterizados ao mesmo tempo do lado da produção [...], e do lado da recepção, na medida em que cada receptor contribui para produzir a mensagem que ele percebe e aprecia.” (BOURDIEU, 2008, p. 25, grifo do autor). Na perspectiva do sociólogo francês, isolar a linguagem de suas condições sociais de produção é ignorar que a resposta para a eficácia simbólica da comunicação não está na linguagem em si, mas no mundo social que a produziu. Logo, relações de comunicação são relações de poder fundadas em um arbítrio, em relações de violência simbólica, socialmente instituídas.

$\mathrm{Na}$ mesma direção, Castells pontua que o poder se exerce fundamentalmente construindo significados na mente humana mediante processos de comunicação que têm lugar nas redes de comunicação de massa, incluída, como destaca o autor, a autocomunicação de massa. Logo, os discursos diários de Bolsonaro, aparentemente frívolos e desarticulados, revelam uma estratégia com alvos bem direcionados quanto à recepção das mensagens, a começar pela claque ruidosa presente a esta modalidade de entrevista coletiva. A demonização da imprensa valida, em contrapartida, a estrutura das fake news. Dia após dia, ao longo dos primeiros 500 dias de mandato, o presidente fez dessa prática uma parte importante do seu modus operandi, convergindo para parte da ritualística do poder um componente de histrionismo agressivo que mira o teor informativo a ser disseminado. Diz Castells: "Ainda que as teorias sobre o poder e a observação histórica apontem para a importância do 
PERcursos Linguísticos • Vitória (ES) •v. 10 •n. 25 • 2020 • ISSN: 2236-2592 • Dossiê:

Discursos de resistência e corpos (re)existentes •

monopólio da violência por parte do estado (...), a capacidade para empregar com êxito a violência ou a intimidação requer o enquadramento individual e coletivo das mentes." (CASTELLS, 2009, p. 535). Nisto consiste, em grande parte, o teor irascível que emana do arremedo de entrevistas coletivas na Brasília comandada por Jair Bolsonaro.

\section{Considerações finais}

A atividade jornalística na seara política, especialmente para repórteres lotados nas sucursais dos veículos na capital federal, tornou-se uma atividade de risco. Em boa medida, pelas posturas e atitudes adotadas pelo presidente da República, Jair Bolsonaro, no contato diário com estes profissionais. São sessões diárias marcadas por gritos, humilhação, escárnio e desqualificação do trabalho dos jornalistas, o que termina potencializado pela presença de apoiadores do governo que reforçam o discurso do mandatário do país. Uma situação tão limítrofe que, na última semana de maio/2020, vários meios de comunicação, liderados por Folha de S. Paulo e O Globo, anunciaram que deixariam de enviar repórteres para tais sessões. Outros veículos de imprensa os seguiram, poupando seus profissionais do arremedo de entrevista coletiva travestido de afago nos apoiadores, por sua vez incitados a subir o tom contra os jornalistas. Foi o que se viu em 31 de março, quando os xingamentos dos populares levaram a uma retirada da tropa jornalística. Convém ressaltar que, à época da edição final deste artigo, na primeira semana de agosto/2020, o (des)encontro matutino de Bolsonaro com os repórteres foi praticamente suspenso, em parte para evitar-se aglomerações como recomendado pela pandemia do novo coronavírus, aliás, recomendação seguidamente descumprida pelo presidente em encontros de rua com seus apoiadores.

A ruptura ocorrida em maio/2020 representou uma quebra na relação de tácito respeito que marcou, na história republicana brasileira, a relação entre poder e mídias. Fonseca, do IPEA (Instituto de Pesquisa Econômica e Aplicada), informa que a história brasileira é atravessada por episódios nos quais a imprensa teve papel decisivo no curso de eventos que produziram impactos substantivos na estrutura sociopolítica do país. Ele também chama a atenção para o fato de que a mídia, concebida como ator político-ideológico, representa uma das instituições mais eficazes quanto "à inculcação de ideias junto a grupos estrategicamente reprodutores de opinião, caracterizando-se como polos de poder.” (Fonseca, 2010, p. 16).

Curiosamente, no dia anterior ao infeliz episódio das bananas oferecidas aos profissionais por um comediante travestido de presidente, o governo reeditou e publicou uma 
PERcursos Linguísticos • Vitória (ES) •v. 10 •n. 25 • 2020 • ISSN: 2236-2592 • Dossiê:

Discursos de resistência e corpos (re)existentes •

cartilha de 2018 sobre a proteção de jornalistas e outros comunicadores. O documento traz as obrigações governamentais acerca da prevenção, proteção e acesso à justiça em casos de violência cometida contra esses profissionais em razão do exercício do seu direito à liberdade de pensamento e expressão. Entre as obrigações do governo, incluem-se a de fazer discursos públicos que contribuam para prevenir a violência contra jornalistas e comunicadores e campanhas e capacitações de agentes do Estado sobre o papel desses profissionais em sociedades democráticas, diz o documento. Exatamente o oposto das ações do presidente.

A atual gestão levou às últimas consequências o que o professor Marcondes Filho vem apontando em seus livros acerca da precarização da atividade dos jornalistas. "O trabalho aumentou, o contingente foi reduzido, as responsabilidades se tornaram mais individuais." (Marcondes Filho, 2009, p. 61) No atual momento da democracia brasileira, esses riscos se tornam ainda mais evidenciadas, como é exemplo o escárnio com que são tratados estes profissionais. Dos encontros no cercadinho [também classificado informalmente de “chiqueirinho"], quando não há produção de fatos, senão das diatribes de um presidente preocupado, como um monarca aparvalhado, a falar a seu séquito e ser por ele incensado, com prejuízo para os profissionais colocados em situação vexatória.

Enfim, acreditamos que a ferramenta analítica oferecida pela ACD permite voltar nosso olhar para este novo cenário no caso brasileiro, em particular, e buscar compreender de que maneira tais encenações buscam, de maneira sub-reptícia ainda que discursivamente explícita, atuar como cortina de fumaça para evitar a abordagem, pelos repórteres, de assuntos espinhosos e polêmicos no cotidiano de governos. Como afirma van Dijk, vemos que a produção e o entendimento do texto e da fala implicam fundamentalmente o que tradicional e informalmente se conhece como o contexto deste discurso, "o que compreende categorias como a identidade e papel do participante, a instituição, o lugar, o momento, as ações políticas e os artifícios a elas relacionadas" (VAN DIJK, 2017, p. 21-22). E, claramente, compreende as estratégias e táticas diversionistas e manipuladoras de discursos articulados desde um lugar e com propósitos evidentes. 
PERcursos Linguísticos • Vitória (ES) •v. 10 •n. 25 • 2020 • ISSN: 2236-2592 • Dossiê:

Discursos de resistência e corpos (re)existentes •

\section{Referências:}

BOURDIEU, P. A economia das trocas linguísticas: O que falar quer dizer. São Paulo: EDUSP, 2008.

CASTELLS, M. Comunicación y poder. Madrid: Alianza Editorial, 2009.

CHAUÍ, M. Simulacro e Poder. Uma análise da mídia. São Paulo: Editora Fundação Perseu Abramo, 2006.

CHARAUDEAU, P. Discurso das Mídias. São Paulo: Editora Contexto, 2015. . El discurso de información: La construcción del espejo social. Barcelona: Gedisa, 2003.

FAIRCLOUGH, N. Discurso e Mudança Social. Brasília: Editora UnB, 2003.

FONSECA. F. Mídia e Poder: elementos conceituais e empíricos para o desenvolvimento da democracia brasileira. Brasília: Editor IPEA. Setembro/2010.

FOWLER, R. Language in the News: Discourse and Ideology in the Press. Londres: Routledge, 1991.

MARCONDES FILHO, C. Ser jornalista: O desafio das tecnologias e o fim das ilusões. São Paulo: Paulus, 2009.

MEDINA, C. Entrevista, o diálogo possível. São Paulo: Editora Ática, 1986.

SODRÉ, M. A narração do fato: Notas para uma teoria do acontecimento. Petrópolis: Vozes, 2012 .

VAN DIJK, T. La noticia como discurso. Comprensión, estructura y producción de la información. Barcelona: Paidós, 1990.

Discurso y poder. Barcelona: Gedisa, 2009.

. Discurso y Contexto: Un enfoque sociocognitivo. Barcelona: Gedisa, 2017.

. Ideología y Discurso. Barcelona: Ariel, 2011. 